SSSR V BOR'BE ZA MIR NAKANUNE VTOROI MIROVOI VOINY (SENTIABR' 1938 G.-AVGUST 1939 G.): DOKUMENTY I MATERIALY. Edited by $A$. A. Gromyko et al. Moscow: Politizdat, 1971. 736 pp. 1.44 rubles.

The purpose of this collection of documents is to substantiate the familiar contention of Soviet historians that the Soviet Union alone stood for genuine collective security in the period before the Second World War, while the Western Powers were chiefly concerned to stimulate German interest in eastward expansion and to connive at her aggression, provided it was at the Soviet Union's expense. The documents themselves come partly from the Soviet archives and partly from Western sources-British, German, American, Italian, Polish. Most of the latter have been published elsewhere in the original. Of the documents from the Soviet archives, most are telegrams from Soviet missions and military attachés abroad. Some appear to be interceptions of documents originating with foreign governments.

The Soviet documents bear out the editors' contention that events and plans of foreign governments were followed closely. They also serve to illustrate the political activities of Soviet diplomats, notably Maisky in London-giving, for instance, accounts of his conversations with Beaverbrook and Lloyd George. The Soviet authorities also followed closely the final stages of the "appeasement" policy, whether carried out on the British government's behalf or by self-appointed intermediaries.

Since it presumably will be some time before the regular series of Soviet documents reaches these years, this material is useful to help assess the background against which the Soviet government decided to come to terms with Nazi Germany. On the other hand, the documents add nothing whatever to our knowledge of SovietGerman relations themselves. The editors refer, of course, to the Soviet-German nonaggression pact but print neither its text nor any documents dealing with the conversations that led up to its conclusion. It is not merely that the Soviet archives are not called upon to furnish any new material; but this is the only subject for which Western documentary collections are not used. The documents from the German archives that have been available in print for a quarter-century are totally ignored, and Ciano's diary, which is used on certain points, is not referred to for its reflections of Germany's Soviet policy.

For the Western reader this is not important; but it is important for an understanding of the Soviet attitude toward foreign policy even today. If the Soviet Union remains the one major power that cannot face the realities of its own past, that is an important fact which we would do well to recognize; since it must be assumed that it is partial collections of this kind that are now used in the training of Soviet youth for their international role.

\author{
Max Beloff \\ All Souls College, Oxford
}

\title{
IANTARNYI KRAI: TRAGEDIIA GORODA LIBAVY I GIBEL' ROSSII- SKOI IMPERII. By Ivan Ebershtein. New York, 1970. 327 pp. Paper.
}

This book offers an intriguing combination of memoirs and folklore. Without entering into problems of interpretation and politics, I would recommend it strongly to those attempting to steep themselves in the history and culture of the Baltic 